\title{
Soy isoflavones improves endometrial barrier through tight junction gene expression
}

\author{
Pongpat Kiatprasert, Chatsri Deachapunya ${ }^{1}$, Chutamas Benjanirat and Sutthasinee Poonyachoti \\ Department of Physiology, Faculty of Veterinary Science, Chulalongkorn University, Henri-Dunant Road, Patumwan, \\ Bangkok 10330, Thailand and ${ }^{1}$ Department of Physiology, Faculty of Medicine, Srinakharinwirot University, \\ Sukhumvit Road, Bangkok 10110, Thailand
}

Correspondence should be addressed to S Poonyachoti; Email: sutthasinee.p@chula.ac.th

\begin{abstract}
Contamination with bacterial endotoxin causes the disruption of the tight junction (TJ) barrier. We investigated the ameliorative effect of dietary flavonoids genistein (Ge) and daidzein (Di) in normal or lipopolysaccharide (LPS)-induced disruption of epithelial barrier function of the endometrium. Using the immortalized porcine glandular endometrial epithelial cells (PEG), transepithelial electrical resistance (TER) and FITC-dextran flux (FD-4) across the monolayer were measured. The mRNA expression of TJ proteins, zona occludens-1 (ZO1), and claudin-1, -3, -4, -7 and -8 was evaluated by real-time RT-PCR for coinciding effect of Ge or Di occurred at the gene transcription level. The results revealed that $\mathrm{Ge}$ and $\mathrm{Di}$ altered the TER, depending on times and concentrations. Low concentration $\left(10^{-10} \mathrm{M}\right)$ of both compounds decreased the TER, whereas higher concentrations $\left(10^{-8}\right.$ and $\left.10^{-6} \mathrm{M}\right)$ increased the TER which was not related to the FD-4 flux. The increased TER by Ge or Di was parallel to the induction of claudin-3 and -4 or -8 mRNA expression respectively. With LPS inoculation, all isoflavone treatments inhibited the decreased TER induced by LPS, but only Ge (10 ${ }^{-8}$ or $10^{-6} \mathrm{M}^{-6}$ or $\mathrm{Di}\left(\mathrm{10}^{-10}\right.$ or $\left.10^{-6} \mathrm{M}\right)$ was coincidence with the decreased FD-4 flux. Under this LPS-stimulated condition, some or all examined TJ gene expressions appeared to be promoted by specific concentration of Ge or Di respectively. Our findings suggest that the soy isoflavones treatment could promote and restore the impaired endometrial barrier function caused by LPS contamination.

Reproduction (2015) 149 269-280
\end{abstract}

\section{Introduction}

Tight junction (TJ) of endometrial epithelial cells employs physical barriers in the regulation of ion transport via a paracellular pathway. The paracellular barrier function provides the tightness against uncontrolled leak flux as well as the maintenance of mucosal monolayer integrity that contributes to endometrial health (Wira et al. 2010). The disruption of TJ of endometrial epithelial cells may result in the major implication in reproductive failure, such as infertility, infection, and chronic abortion. TJ is a complex of membrane-bound proteins, occludin and claudins, and their adaptors and scaffolding proteins (e.g., junctional adhesion molecule, zona occludens (ZO)-1, ZO2, and ZO3) (Förster 2008, Van Itallie \& Anderson 2013). The largest family of TJ proteins is the claudins. At least 24 members of claudins have been identified. Claudins are $20-27 \mathrm{kDa}$, tetraspan proteins with relatively short and highly variable cytoplasmic amino and carboxy termini, flanking a first extracellular loop of 53 amino acids and a second shorter loop of 24 amino acids (Amasheh et al. 2011). In order to form the TJ barrier complex, the carboxy terminus of claudins binds to
Zonula occluden-1 (ZO1) and to related ZO2 and ZO3 proteins. In gastrointestinal epithelia, TJ regulates the entry of nutrients, ions, and water while restricting pathogen entry. Besides, it is constantly being remodeled when interacts with external stimuli, such as food residues and pathogenic and commensal bacteria (Ulluwishewa et al. 2011). Various diseases have been proven to link with claudin mutation. Furuse et al. (2002) have reported of claudin-1-deficient mice dying after birth as a result of dehydration. Bacterial endotoxin, lipopolysaccharides (LPSs), or Clostridium perfringens enterotoxin (CPE) has been shown to decrease claudin-1, -3 , or -4 expression, causing the loss of intestinal TJ barrier function (Sonoda et al. 1999, Fujita et al. 2012).

In the reproductive tissues, expression of claudin-1, $-3,-4,-5$, and -7 has been indicated in human endometrium. Generally, claudin- $1,-3,-4$, and -8 are considered barrier-forming claudins to increase the epithelial tightness, whereas claudin-2 and -7 are poreforming claudins known to decrease the epithelial tightness. The decreases in claudin-3 and -4 or increases in claudin- 2 and -7 expression cause the increases in tissue permeabilities, which have been suggested to associate with ectopic endometriosis and various 
endometrial cancer (Gonzalez-Mariscal et al. 2003, Pan et al. 2007, Gaetje et al. 2008). Human immunodeficiency syndrome virus (HIV) employs the defective TJ barrier function through the downregulated claudin-3 and -4 mRNA expression and leads to microbial translocation including LPS to initiate mucosal transmission of HIV and HIV disease progression (Nazli et al. 2010). Thus, the increased paracellular permeability as reflected by the reduced transepithelial electrical resistance (TER) may associate with the leakiness of TJ and allow normally excluded molecules across the epithelium, resulting in inflammation and pathological conditions in reproductive system or any others.

TJ proteins are regulated by sex steroid hormones, particularly estrogen and progesterone (Satterfield et al. 2007, Bailey et al. 2010). Isoflavonoids, a class of phytoestrogens mainly found in soy-based foods, which have been evidenced for both estrogenic and antiestrogenic actions, may modify the TJ barrier expression and function (Brooks \& Skafar 2004, Rietjens et al. 2013). Genistein (Ge) and daidzein (Di) are the major isoflavones in soybeans, being extensively studied because of their pharmacological and beneficial effects (Wang \& Murphy 1994, Banerjee et al. 2008). Their effects on the prevention of hormone-dependent breast and prostate cancers are best understood (Barnes et al. 1994). Although little is known regarding the effect of soybean isoflavones on TJ barrier function in the endometrium, some studies in the gastrointestinal epithelium have shown the effects of soy isoflavones, especially Ge on the protection of TJs barrier function induced by oxidative stress. Ge has been reported to inhibit the decreased TER and $\left[{ }^{3} \mathrm{H}\right]$-mannitol flux as indicators of TJ permeability induced by superoxide anion production in human colonic cell line Caco-2 (Rao et al. 2002). The mechanism of Ge action is reported to block the dissociation of TJs, ZO1 and occludins, mediated by tyrosine kinase (Atkinson \& Rao 2001). Furthermore, Ge has been reported to block the impairment of TJs barrier function induced by Salmonella typhimurium and Escherichia coli in Caco-2 cells (Wells et al. 1999).

In previous studies, the immortalized porcine glandular endometrial epithelial cell culture (PEG) was characterized and represented as the normal cell culture for examining the effects of $\mathrm{Ge}$ and $\mathrm{Di}$ on the epithelial function (Palmer et al. 2008, Deachapunya \& Poonyachoti 2013). Thus, in this study, we aimed to investigate whether the soy isoflavones, Ge or $\mathrm{Di}$, alter the endometrial barrier function in the PEG cells as determined by TER and FITC-dextran flux (FD-4). The mechanism of TER changes by these isoflavones depending on the transcription level of TJs genes in the endometrial tissues, i.e., claudin- $1,-3,-4,-7$, and -8 and its scaffolds ZO1 was also examined. The assessment of the ameliorative effect of Ge and Di on the LPS-induced disruption of epithelial barrier protein and function was finally determined. Understanding the effect of phytoestrogens on endometrial barrier function is critical for uterine health and reproductive success.

\section{Materials and methods}

\section{Materials}

Ge, Di, insulin, nonessential amino acid, LPS (E. coli 0111:B4, purified by phenol extraction), and high purity grade salts were purchased from Sigma Chemical Co. DMEM, Dulbecco's PBS (DPBS), phenol red-free DMEM, fetal bovine serum (FBS), $0.05 \%$ trypsin-0.53 mM EDTA, kanamycin, and penicillinstreptomycin were purchased from Gibco BRL. Charcoalstripped (cs) FBS was purchased from Biowest Co. (Miami, $\mathrm{FL}, \mathrm{USA})$.

\section{Cell culture}

Immortalized PEG cells were kindly provided by Prof. Scott $\mathrm{O}^{\prime} \mathrm{Grady}$, University of Minnesota. The cells were cultured in DMEM supplemented with $3.7 \mathrm{~g} / \mathrm{l} \mathrm{NaHCO}_{3}, 5 \%$ heat-inactivated FBS, $850 \mathrm{nM}$ insulin, $1 \%$ non-essential amino acids, $100 \mathrm{U} / \mathrm{ml}$ penicillin, $100 \mu \mathrm{g} / \mathrm{ml}$ streptomycin, and $100 \mu \mathrm{g} / \mathrm{ml}$ kanamycin (standard medium), and incubated at $37^{\circ} \mathrm{C}$ in a humidified atmosphere of $5 \% \mathrm{CO}_{2}$ in the air. Before the experiment, the PEG cells were subcultured onto $12 \mathrm{~mm}$ diameter transwell insert filters with $0.4 \mu \mathrm{m}$ membrane pore size. The cell monolayers were fed every 2 days and maintained in the standard media for about 7 days. In an effort to verify the possible regulation of $\mathrm{Ge}$ or $\mathrm{Di}$ on the epithelial barrier function, the standard cell culture medium was replaced with phenol red-free medium containing $2 \%$ csFBSDMEM and other supplements identical to the standard medium for 2 days and subjected to drug treatment.

\section{Measurement of endometrial TJ barrier function}

Porcine endometrial TJ barrier function was evaluated by the measurements of TER and the unidirectional flux of FITCconjugated dextran (FD-4; average molecular weight 4000) across PEG monolayers in transwell inserts. TER was performed to determine the permeability of TJ lining at the uppermost portion of endometrial epithelial cells. Following the subculture of PEG cells on the transwell inserts, the TER was periodically measured by using EVOM ${ }^{2}$ electrode connected to volt-ohmmeter (World Precision Instruments, Inc., Sarasota, FL, USA) over 24-h intervals before and after drug treatment. To monitor the changes in TER with phytoestrogens and LPS stimulation, the PEG cells grown in $2 \%$ csFBS-DMEM for 2 days were measured for TER. After that, Ge or Di $\left(10^{-10}\right.$, $10^{-8}$, or $10^{-6} \mathrm{M}$ ) or their vehicle DMSO were applied to the apical side of cell monolayer and incubated for $48 \mathrm{~h}$. The TER was measured before (0 min) and at $30 \mathrm{~min}, 1,2,24$, and $48 \mathrm{~h}$ after administration of drugs. Percent changes in TER at each time point from the starting point were calculated and analyzed.

For measurement of paracellular unidirectional flux, FITC-conjugated dextran (FD-4; $1 \mathrm{mg} / \mathrm{ml}$ ) prepared in 
HEPES-buffered salt solution (HBSS): HEPES (25 mM), $\mathrm{NaCl}$ (120 mM), KCl (5.4 mM), $\mathrm{CaCl}_{2}(1.8 \mathrm{mM}), \mathrm{NaHCO}_{3}(25 \mathrm{mM})$, glucose $(15 \mathrm{mM})$ was added to the apical side of the filtergrown PEG monolayers after $48 \mathrm{~h}$ treatment with isoflavonoids or LPS. After incubation of FD-4 for $4 \mathrm{~h}$ at $37^{\circ} \mathrm{C}$, media samples from the basolateral side were collected and fluorometrically determined at excitation $492 \mathrm{~nm}$ and emission $535 \mathrm{~nm}$ (Infinite 200 PRO, Tecan, Männedorf, Germany).

\section{LPS stimulation}

To examine the effect of Ge and Di on bacterial endotoxininduced TJ disruption, the PEG cells pretreated with drugs or vehicle for $48 \mathrm{~h}$ were replaced with fresh $2 \%$ csFBS-DMEM, containing $1 \mu \mathrm{g} / \mathrm{ml}$ of O111:B4 E. coli LPSs plus isoflavones and further incubated for $48 \mathrm{~h}$. The measurement of TER was performed before (0 $\mathrm{min}$ ) and at $30 \mathrm{~min}, 1,2,24$, and $48 \mathrm{~h}$ after LPS stimulation. The percent changes in TER at each time point of 48-h isoflavones or vehicle treatment before and after LPS stimulation were calculated and compared. The cells from each cell culture insert were then harvested, and the total RNA was extracted for the analysis of TJs mRNA expression.

\section{$R T$ and semiquantitative real-time PCR}

To determine the level of mRNA expression, the PEG cells on the cell insert treated with drugs following with or without LPS stimulation for $48 \mathrm{~h}$ were subjected to RNA extraction using Trizol (Life Technologies). After precipitation with absolute ethanol, the RNA pellet was collected and diluted with diethylpyrocarbonated-treated water and determined for quantity and quality by spectrophotometry (NanoDrop; Thermo Scientific, Wilmington, DE, USA) at the absorbance wavelength of 260 and $280 \mathrm{~nm}$. RNA samples with a ratio of absorbance at $260 / 280 \mathrm{~nm}$ in the range of $1.8-2.0$ were accepted for analysis. Total RNA were reverse-transcribed to the first-strand cDNA using the iScript Select cDNA Synthesis Kit (Bio-Rad Laboratories). The protocol was performed according to the manufacturer's instructions. Briefly, total RNA $(3 \mu \mathrm{g})$ was denatured at $65^{\circ} \mathrm{C}$ for $5 \mathrm{~min}$, and then reverse-transcribed in a final volume of $20 \mu$ of the reaction mixture with oligo- $(\mathrm{dT})_{20}$ primer, iScript reverse transcriptase in the condition of $25{ }^{\circ} \mathrm{C}$ for $5 \mathrm{~min}, 42{ }^{\circ} \mathrm{C}$ for $30 \mathrm{~min}$ for primertemplate hybridization and polymerization, and ended with $85^{\circ} \mathrm{C}, 5$ min for inactivation of the enzyme using the Gradient Thermocycler (Whatman Biometra, Goettingen, Germany). The cDNA product was stored at $4{ }^{\circ} \mathrm{C}$ until use. For the realtime PCR analysis, all primers as given in the Table 1 were designed by using The Primer Express Software Version 3.0 (Applied Biosystems) and prepared by Biosearch Technologies (Novato, CA, USA). For semi-quantitative analysis, the glyceraldehyde-3-phosphate dehydrogenase (GAPDH) cDNA was also amplified as an internal control.

To optimize the number of amplification cycles for all examined genes, conventional PCR was performed by the TopTaq Mastermix Kit (Qiagen) for 17-40 rounds using the PEG cells grown in the standard medium according to the manufacturer's manual. The reaction contained TopTaq Master Mix (1.25 units of TopTaq DNA polymerase, TopTaq PCR buffer
Table 1 Primers used for real-time PCR of tight junction genes.

\begin{tabular}{|c|c|c|}
\hline $\begin{array}{l}\text { Tight } \\
\text { junction } \\
\text { genes } \\
\end{array}$ & Primer sequence $\left(5^{\prime} \rightarrow 3^{\prime}\right)$ & $\begin{array}{l}\text { GenBank } \\
\text { accession number }\end{array}$ \\
\hline Claudin-1 & $\begin{array}{l}\text { Fwd: CCCGGTCAATGCCAGATATG } \\
\text { Rev: CACCTCCCAGAAGGCAGAGA }\end{array}$ & NM_001161635.1 \\
\hline Claudin-3 & $\begin{array}{l}\text { Fwd: CATTATCACAGCGCGGATCA } \\
\text { Rev: CGTACACTTTGCACTGCATCTG }\end{array}$ & NM_001160075.1 \\
\hline Claudin-4 & $\begin{array}{l}\text { Fwd: GTGTAAGGTGCTACCGCTGATTC } \\
\text { Rev: AGGGCCATTCTGGAGTCACA }\end{array}$ & NM_001161637.1 \\
\hline Claudin-7 & $\begin{array}{l}\text { Fwd: CCATGACTGGAGGCATCATTT } \\
\text { Rev: GACAATCTGGTGGCCATACCA }\end{array}$ & NM_001160076.1 \\
\hline Claudin-8 & $\begin{array}{l}\text { Fwd: TGGGAAGGACTGTGGATGAAC } \\
\text { Rev: AGAGCCAGCAGGGAATCGTA }\end{array}$ & NM_001161646.1 \\
\hline ZO1 & $\begin{array}{l}\text { Fwd: AAAAGTGAACCACGAGATGCT } \\
\text { Rev: AAAGGTGGAGGACTGGAGATGA }\end{array}$ & NC_010443.4 \\
\hline GAPDH & $\begin{array}{l}\text { Fwd: GCA GGT CAG GTC CAC AA } \\
\text { Rev: TTC CAC GGC ACA GTC AA }\end{array}$ & NM_001206359.1 \\
\hline
\end{tabular}

with $1.5 \mathrm{mM} \mathrm{MgCl}_{2}$ and $200 \mu \mathrm{M}$ each dNTP) and $400 \mathrm{nM}$ of each primer. The amplification was performed by Gradient Thermocycler (Whatman Biometra) for 45 cycles starting with enzyme activation at $94{ }^{\circ} \mathrm{C}$ for $3 \mathrm{~min}$ followed by denaturation at $94{ }^{\circ} \mathrm{C}$ for $30 \mathrm{~s}$, annealing at $60{ }^{\circ} \mathrm{C}$ for $30 \mathrm{~s}$ and at $72{ }^{\circ} \mathrm{C}$ for $1 \mathrm{~min}$ for extension followed by $10 \mathrm{~min}$ incubation at $72{ }^{\circ} \mathrm{C}$ for final extension. The PCR products were analyzed by $1.5 \%$ agarose gel electrophoresis and stained with ethidium bromide for visualization under u.v light. The amounts of amplicons of all interested genes were linearly increased from 30 to 40 cycles. Therefore, the numbers of amplification cycles were fixed in the 40 cycles. To study the relative quantitative expression of the targeted gene with the housekeeping gene, semiquantitaive PCR was performed with Corbett Rotor Gene 6000 (Qiagen) and Evaline EvaGreen E4 Supermix (GeneOn Biotech, Ludwigshafen am Rhein, Germany) containing EvaGreen dye, $400 \mathrm{nM}$ of each primer and $150 \mathrm{nM}$ of the template were mixed in 20- $\mu$ l reaction. The amplification reaction was performed for 40 cycles, starting with enzyme activation at $95^{\circ} \mathrm{C}$ for $3 \mathrm{~min}$ following with denaturation $\left(95^{\circ} \mathrm{C}, 30 \mathrm{~s}\right)$, annealing $\left(60^{\circ} \mathrm{C}, 30 \mathrm{~s}\right)$, and extension $\left(72{ }^{\circ} \mathrm{C}, 30 \mathrm{~s}\right)$. The interested gene expression was analyzed using the relative method $\left(2^{\left(-1 \times \Delta C_{\mathrm{T}}\right)}\right)$, which normalized the threshold cycle $\left(\mathrm{C}_{\mathrm{T}}\right)$ of an interested gene to an internal control gene (porcine $G A P D H)$. The relative fold changes in the interested gene expression in response to drug treatment were analyzed using the relative comparative method $\left(2^{\left(-1 \times \Delta \Delta C_{\mathrm{T}}\right)}\right)$, which calculated the fold changes in the interested gene expression in drugtreated group or LPS-inoculated group from the control DMSO group.

\section{Statistical analyses}

All values are presented as mean \pm S.E.M., and $n$ is the number of cell monolayers from at least three different cell culture passages. Statistical analyses were performed using Prism 5.0, GraphPad Software, Inc., San Diego, CA, USA, the differences between the control and experimental means were analyzed using a Student's $t$-test or ANOVA where appropriate. Post-hoc test was additionally performed with the Dunnett's test to compare the differences from control or the Newman-Keuls test to compare the differences between two groups. A $P$ value $<0.05$ was considered to be significant. 


\section{Results}

\section{Effect of Ge and Di on TER}

In the immortalized PEG cells, the baseline values of TER across the cell monolayer before addition of each drug were $1664 \pm 136.0 \Omega \times \mathrm{cm}^{2}(n=18)$. In all experiments, the percent change in TER from the baseline value (\% change in TER from an initial value of time 0 ) was calculated for drug treatment at each time point. Under control conditions, after replacing with the newly tested medium, the percent change in TER increased by $30 \%$ from the initial value in $30 \mathrm{~min}$, gradually decreased to the baseline TER within $24 \mathrm{~h}$, and remained unchanged until $48 \mathrm{~h}$ of the observation period (Fig. 1). In the presence of Ge or $\mathrm{Di}$ in the culture medium, the percent change in TER was variable as shown in Fig. $1 \mathrm{~A}$ and $\mathrm{B}$ respectively. The TER value of cells treated with Ge at
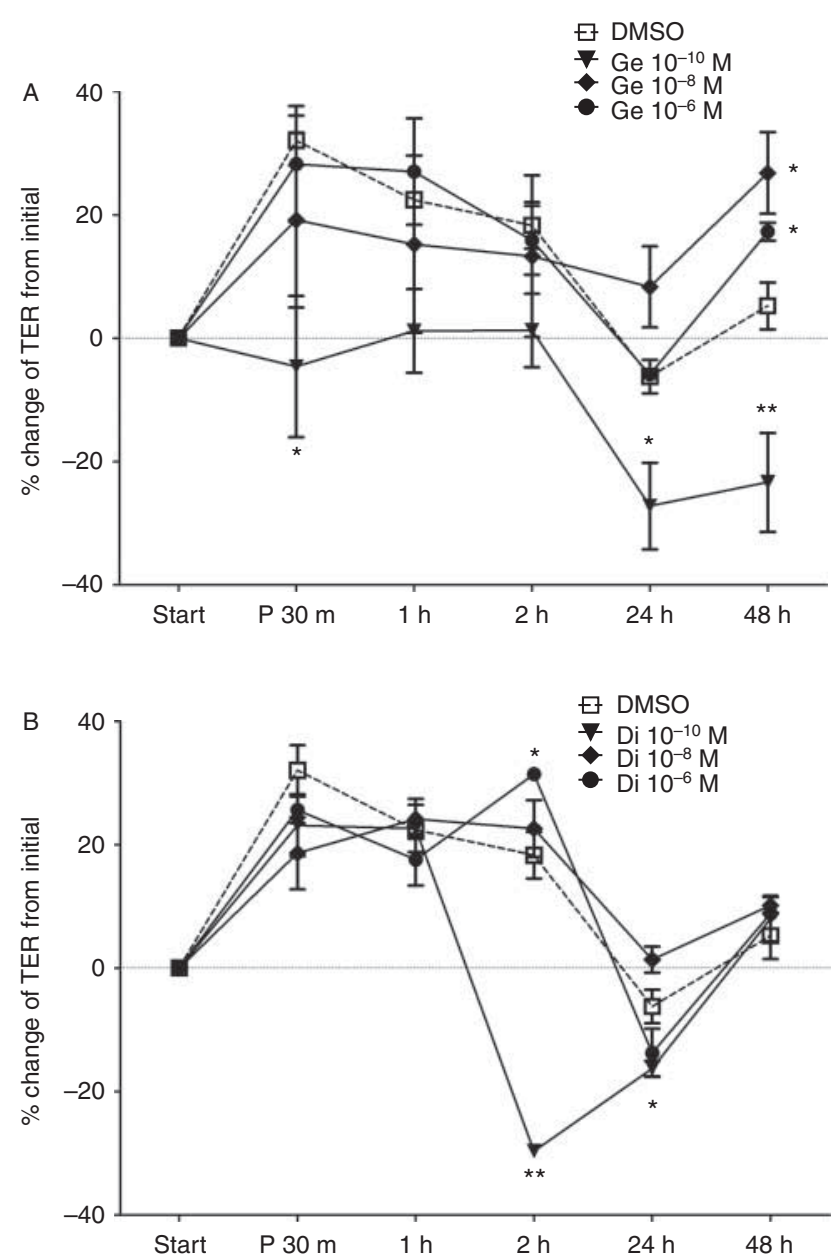

Figure 1 Effects of genistein $(A)$ and daidzein $(B)$ on the percent change in transepithelial resistance (TER) in the PEG cells. The cells were treated for $48 \mathrm{~h}$ with genistein or daidzein at $10^{-10}$ (closed down triangle), $10^{-8}$ (closed diamond) or $10^{-6} \mathrm{M}$ (closed circle) or vehicle control DMSO (open square). The TER was measured at $30 \mathrm{~min}, 1,2$, 24 , and $48 \mathrm{~h}$ following drug treatment. Values are the mean \pm s.E.M. ( $n=6$ in each group). ${ }^{*} P<0.05$ or ${ }^{* *} P<0.01$ denotes difference from control at each time point. low concentration $\left(10^{-10} \mathrm{M}\right)$ slightly decreased by $4 \%$ from the initial value during the first $30 \mathrm{~min}$. The value then remained unchanged for $2 \mathrm{~h}$ before decreasing by $23 \%$ at 24 and $48 \mathrm{~h}$, which was significantly lower than the TER changes observed in the control group. Higher concentration of $\mathrm{Ge}\left(10^{-8}\right.$ or $\left.10^{-6} \mathrm{M}\right)$ showed the profile change in TER during $30 \mathrm{~min}$ to $24 \mathrm{~h}$, similar to the control group, while a significant increase in the TER was observed following 48-h incubation period compared with the control group (Fig. 1A).

Similarly, treatment with $\mathrm{Di}$ at the lowest concentration $\left(10^{-10} \mathrm{M}\right)$ significantly decreased the percent change in TER by $20-30 \%$ during $2-24 \mathrm{~h}$ (Fig. 1B). Nevertheless, the increase in the TER was found after $2 \mathrm{~h}$ incubation with the highest concentration of $\mathrm{Di}$ used in this study $\left(10^{-6} \mathrm{M}\right)$ (Fig. 1B).

\section{Effect of Ge and Di on TER after exposure to LPS}

As LPS has been shown to impair the epithelial barrier function in intestinal Caco-2 cell study (Wells et al. 1993), we further clarified the modulatory effects of soy isoflavones on the LPS-induced epithelial barrier disruption in the endometrial cells. After pretreatment of the PEG cells with Ge or $\mathrm{Di}$ for $48 \mathrm{~h}$, the TER were continually determined following $30 \mathrm{~min}, 1,2,24$, and $48 \mathrm{~h}$ in the presence of LPS and each compound. As shown in Fig. 2, cell exposure to LPS alone $(1 \mu \mathrm{g} / \mathrm{ml})$ increased the percent change in TER by $20-30 \%$ during $30 \mathrm{~min}$ to $2 \mathrm{~h}$ and subsequently decreased the TER by $30 \%$ at 24 and $48 \mathrm{~h}$. Following $2 \mathrm{~h}$ with LPS stimulation, Ge at $10^{-10} \mathrm{M}$ did not affect the TER, but a significant reduction in the TER was observed with $10^{-8}$ or $10^{-10} \mathrm{M}$ Ge treatment as compared with the untreated LPS group. During 24-48 h, the TER of all Ge-treated groups were maintained, which was significantly higher than those of untreated LPS groups (Fig. 2A). Similar to $\mathrm{Ge}$, a pattern of the percent change in TER after LPS stimulation was also observed in Di treatment groups with different concentration responses (Fig. 2B). With LPS stimulation for 24-48 $\mathrm{h}$, the control LPS group continued to decrease the TER lower than the value before LPS stimulation, whereas the TER was restored in all groups receiving either $\mathrm{Di}$ or Ge treatment (Fig. 2A and $\mathrm{B})$.

\section{Effect of Ge and Di on unidirectional FITC-dextran flux}

To further assess the effect of isoflavones on paracellular permeability, FITC FD-4, which is commonly used as a marker of paracellular transport of macromolecules, was additionally performed. As shown in Fig. 3A, pretreatment with Ge or Di for $48 \mathrm{~h}$ had no effect on the apical-tobasolateral FD-4 flux as compared with the control DMSO. Moreover, the FD-4 flux was not affected after continuous culture of cells with LPS alone. However, 

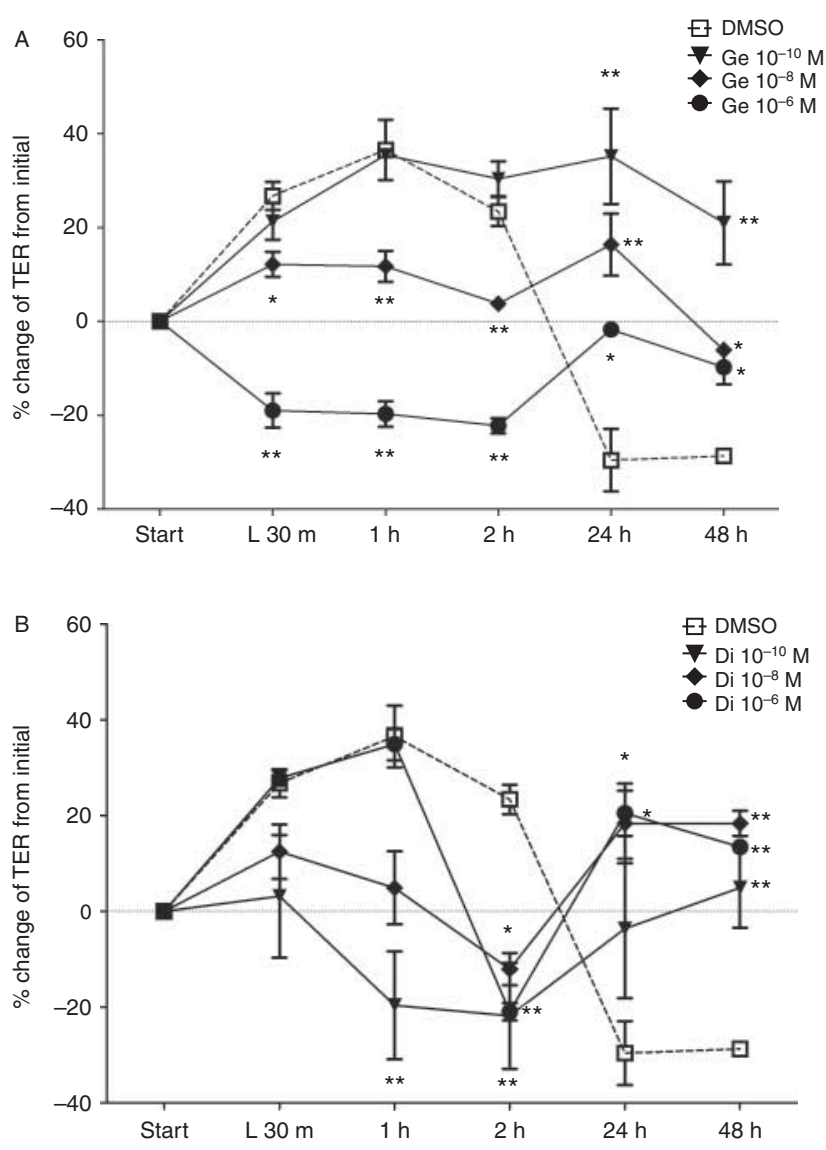

Figure 2 Effects of genistein (A) and daidzein (B) pretreatment on the percent change in transepithelial resistance (TER) in response to lipopolysaccharides (LPS) stimulation in the PEG cells. The cell were incubated with $1 \mu \mathrm{g} / \mathrm{ml}$ of LPS for $48 \mathrm{~h}$ after pretreatment with genistein or daidzein at $10^{-10}$ (closed down triangle), $10^{-8}$ (closed diamond) or $10^{-6} \mathrm{M}$ (closed circle) or vehicle control DMSO (open square). The TER was measured at $30 \mathrm{~min}, 1,2,24$, and $48 \mathrm{~h}$ after LPS stimulation. Values are the mean \pm S.E.M. ( $n=6$ in each group). ${ }^{*} P<0.05$ or ${ }^{* *} P<0.01$ denotes difference from control at each time point.

treatment with Ge at $10^{-8}$ or $10^{-6} \mathrm{M}$ or Di at $10^{-10}$ or $10^{-6} \mathrm{M}$ in the presence of LPS significantly decreased the FD-4 flux, although not in a dose-dependent manner.

\section{Effect of Ge and Di on TJ gene expression}

To evaluate the genomic effects of Ge and Di on TJ gene expression, which are important components of cellular TJs, total RNA of the PEG cells treated with these isoflavones for $48 \mathrm{~h}$ were analyzed by quantitative realtime RT-PCR using primers specific to different TJ genes as appeared in Table 1. Without LPS stimulation, the untreated PGE cells expressed all six TJ genes claudin-1, $-3,-4,-7,-8$, and $Z O 1$ and about one- to 1.5-fold of housekeeping gene GAPDH as shown in Fig. 4. Treatment with $10^{-8} \mathrm{M}$ or $10^{-6} \mathrm{M}$ Ge revealed a twofold increase in claudin-3 mRNA whereas Ge only at $10^{-6} \mathrm{M}$ caused a 1.5 -fold increase in claudin-4 mRNA compared with the corresponding control
(Fig. 5A). In addition, Di at $10^{-6} \mathrm{M}$ or $10^{-8} \mathrm{M}$ increased claudin-8 mRNA expression by twofolds (Fig. 5B, $P<0.05)$. All concentrations of Ge and $\mathrm{Di}$ used in this study did not significantly alter the claudin- $1,-7$, and ZO1 mRNA expression.

\section{Effect of Ge and Di on TJ gene expression after exposure to LPS}

Even though most of the TJ genes being studied were not affected directly by these soy isoflavones, it was worth of studying the modulatory effects of these compounds on the expression of TJ genes in the PEG cells exposed to LPS. Following inoculation with LPS $(1 \mu \mathrm{g} / \mathrm{ml})$ for $48 \mathrm{~h}$, the cells significantly increased the mRNA expression of claudin-7 and ZO1, but decreased the claudin-8 mRNA expression when compared with the cells without LPS exposure (Fig. 4). Treatment of the PEG cells with Ge at
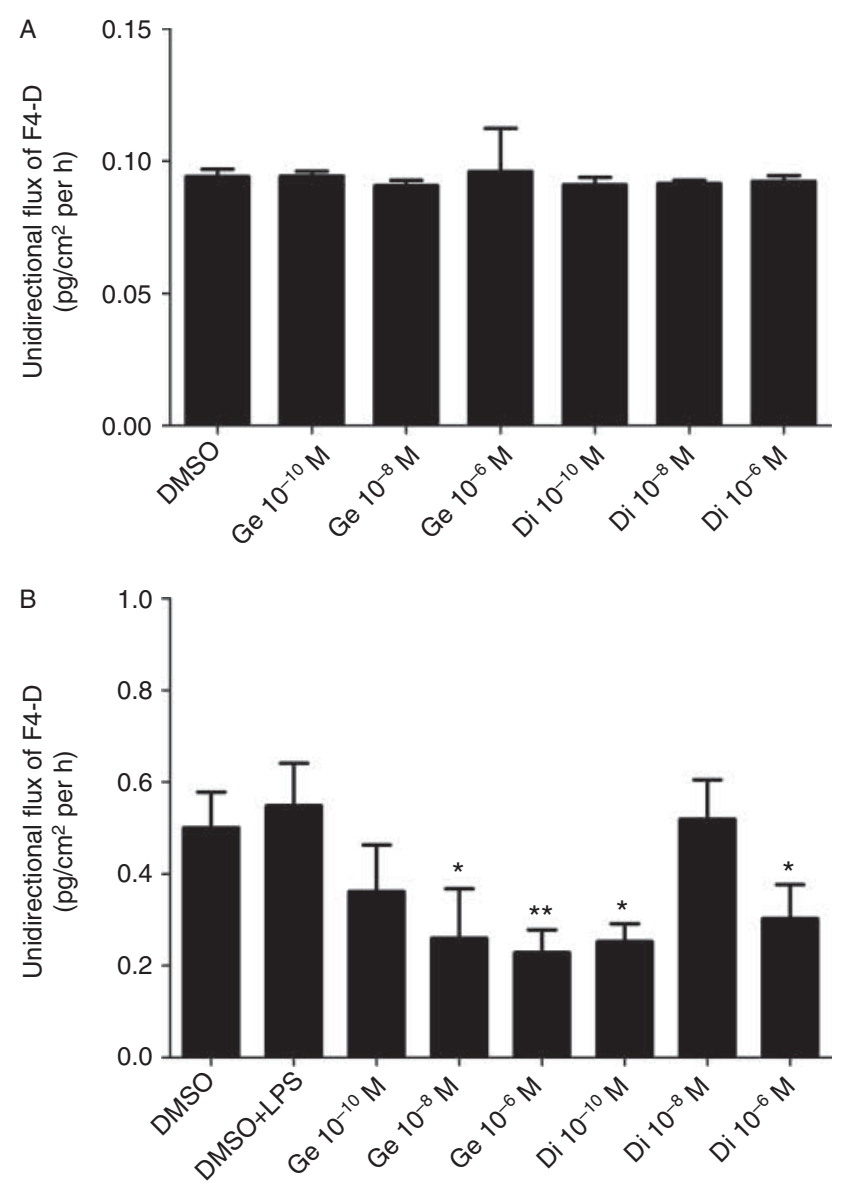

Figure 3 Effects of genistein and daidzein pretreatment on unidirectional FITC-dextran flux (FD-4) in the PEG cells before (A) and after (B) lipopolysaccharides (LPS) stimulation. FD-4 flux was measured across PEG monolayers after incubation with genistein or daidzein at $10^{-10}, 10^{-8}$ or $10^{-6} \mathrm{M}$ or vehicle control DMSO without LPS for $48 \mathrm{~h}$ (A) followed by incubation with drugs with LPS for $48 \mathrm{~h}$ (B). Values are expressed as means \pm S.E.M. ( $n=4$ experiments in each group). $* P<0.05$ or $* * P<0.01$ denotes difference from corresponding control group DMSO (A) or DMSO+LPS (B). 


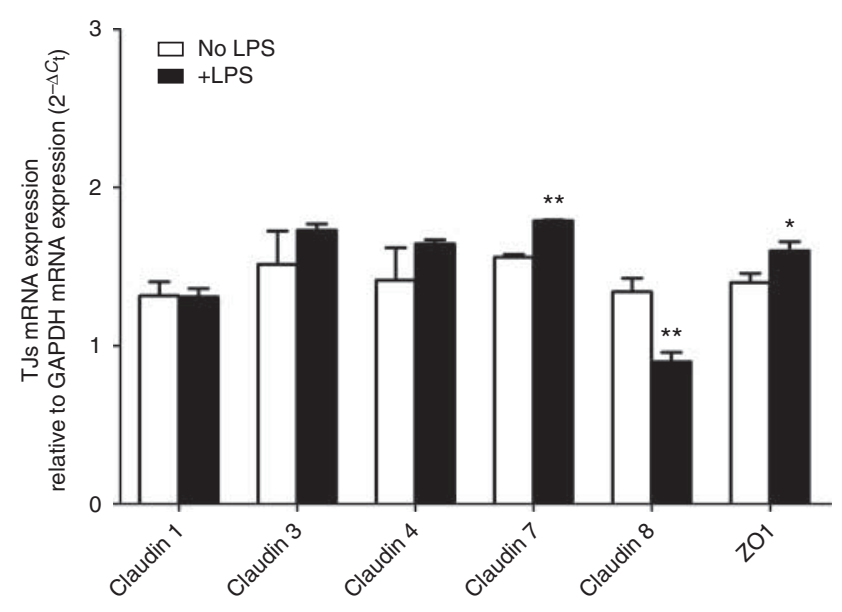

Figure 4 Endogenous mRNA expression tight junction genes claudin-1, $-3,-4,-7,-8, Z O 1$ normalized to housekeeping gene GAPDH in the PEG cells. The cells were cultured without (no LPS) or with $1 \mu \mathrm{g} / \mathrm{ml}$ of LPS (+LPS) for $48 \mathrm{~h}$. Total RNA was analyzed by real-time RT-PCR. Values are the mean \pm S.E.M. ( $n=6$ in each group). ${ }^{*} P<0.05$ or $* * P<0.01$ denotes difference between no LPS and + LPS groups.

$10^{-6} \mathrm{M}$ or Di at $10^{-8} \mathrm{M}$ or $10^{-6} \mathrm{M}$ was found to restore the decreased claudin- 8 mRNA expression being affected by LPS (Fig. 6). Ge at $10^{-6} \mathrm{M}$ also promoted the claudin-4 and/or -7 mRNA expressions in the LPStreated cells (Fig. 6A). Treatment with high and medium concentrations of $\mathrm{Di}\left(10^{-8} \mathrm{M}\right.$ or $\left.10^{-6} \mathrm{M}\right)$ significantly increased by two- to sixfold the expressions of all examined claudins. However, upregulated ZO1 expression in the LPS-treated cells was only found with Di treatment at $10^{-8} \mathrm{M}$.

\section{Discussion}

Epithelial barrier function has a crucial role in health and disease. Destruction of epithelial barrier integrity caused by alterations in $\mathrm{TJ}$ protein structure and function followed by permeation of microorganism from the lumen can induce excessive activation of the mucosal immune system causing tissue damage. Indeed, increases in endometrial permeability are usually found in various reproductive diseases, chronic inflammation, and cancer in particular (Förster 2008). Soybean isoflavones with chemical structure and function similar to the endogenous estrogen have been reported to exhibit ameliorative effects on some of these diseases, although the precise underlying mechanisms remain to be clarified. Ge, $\mathrm{Di}$, and their respective $\beta$-glucoside forms are the primary isoflavones in soybeans and exert higher potency than other flavonoids (Messina 2002). In the previous study using human intestinal Caco-2 cells, $\mathrm{Di}$ and other flavonoids hesperetin, naringenin, and morin that have a different hydroxyl group on A-ring structure from the other flavonoids show the enhancing effect on the barrier integrity, while Ge has the neutralized effect (Noda et al. 2012).
In this study, the aglycone Ge and Di were used because the presence of these two aglycones (unconjugated form) was found to be higher in soy food than $\beta$-glycosides (conjugated form) (Setchell 1998). Moreover, only unconjugated form exerts estrogenic effects on the target organs. Even though in the intestinal tissues and liver the isoflavones are metabolized to the compounds with lesser effect, the plasma concentration of total flavonoid derivatives ranging from 0 to $4 \mu \mathrm{M}$ is equivalent to an intake of $50 \mathrm{mg}$ aglycone (Manach et al. 2005). The plasma aglycone will reach and accumulate in the target organs including uterus to produce many biological effects (Chang et al. 2000). Recent study by Bitto et al. (2010) has revealed that an ingestion of Ge at a dose of $54 \mathrm{mg} /$ day is an effective suppression dose in the treatment of endometrial hyperplasia. As has been reported in many observations that Ge in particular usually shows biphasic effects depending on
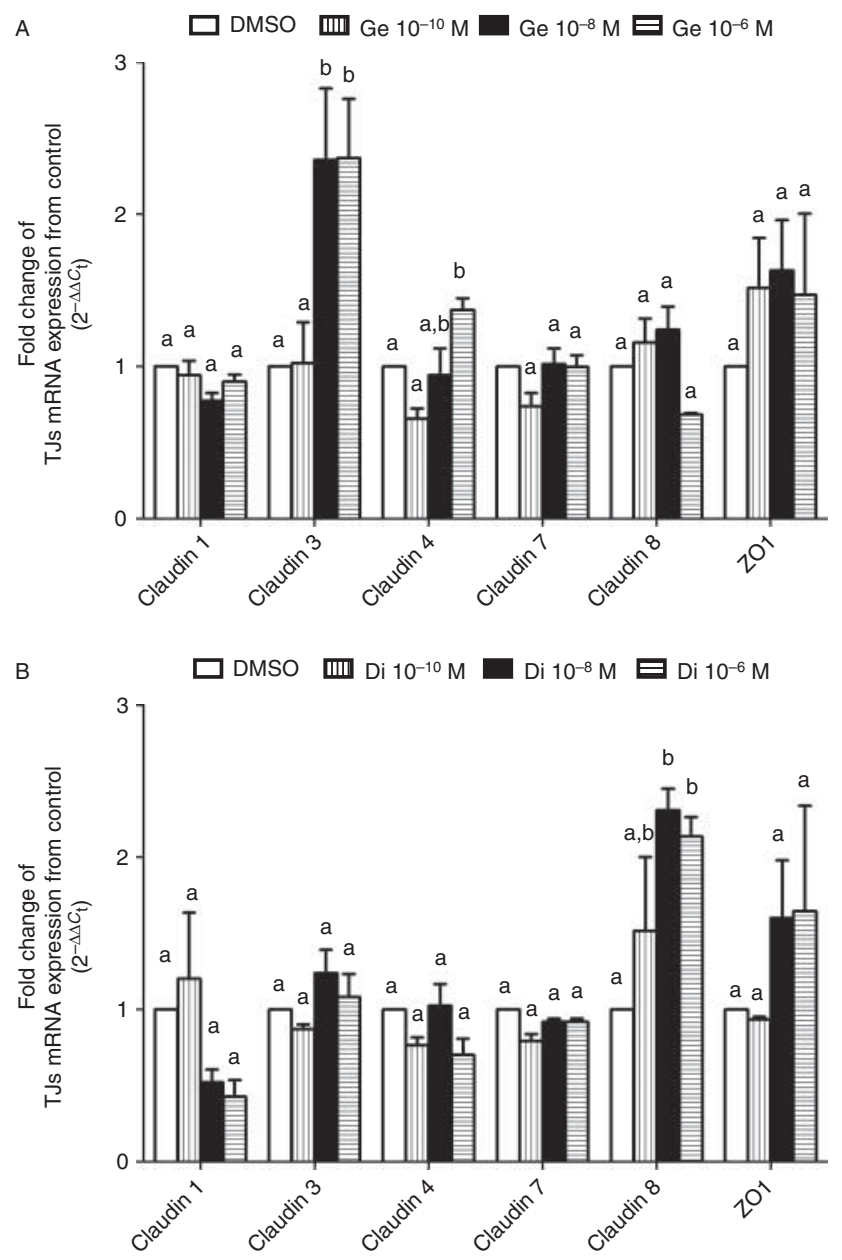

Figure 5 Effects of genistein (A) and daidzein (B) on the relative fold change in mRNA expression of tight junction genes claudin-1, -3, -4, $-7,-8, Z O 1$ in the PEG cells. The cells were treated for $48 \mathrm{~h}$ with genistein or daidzein at $10^{-10}, 10^{-8}$ or $10^{-6} \mathrm{M}$ or vehicle control DMSO. Total RNA was analyzed by real-time RT-PCR. Values are the mean \pm s.E.M. ( $n=6$ in each group). Scale bars with different letters $(a, b)$ mean significantly different at $P$ value $<0.05$. 

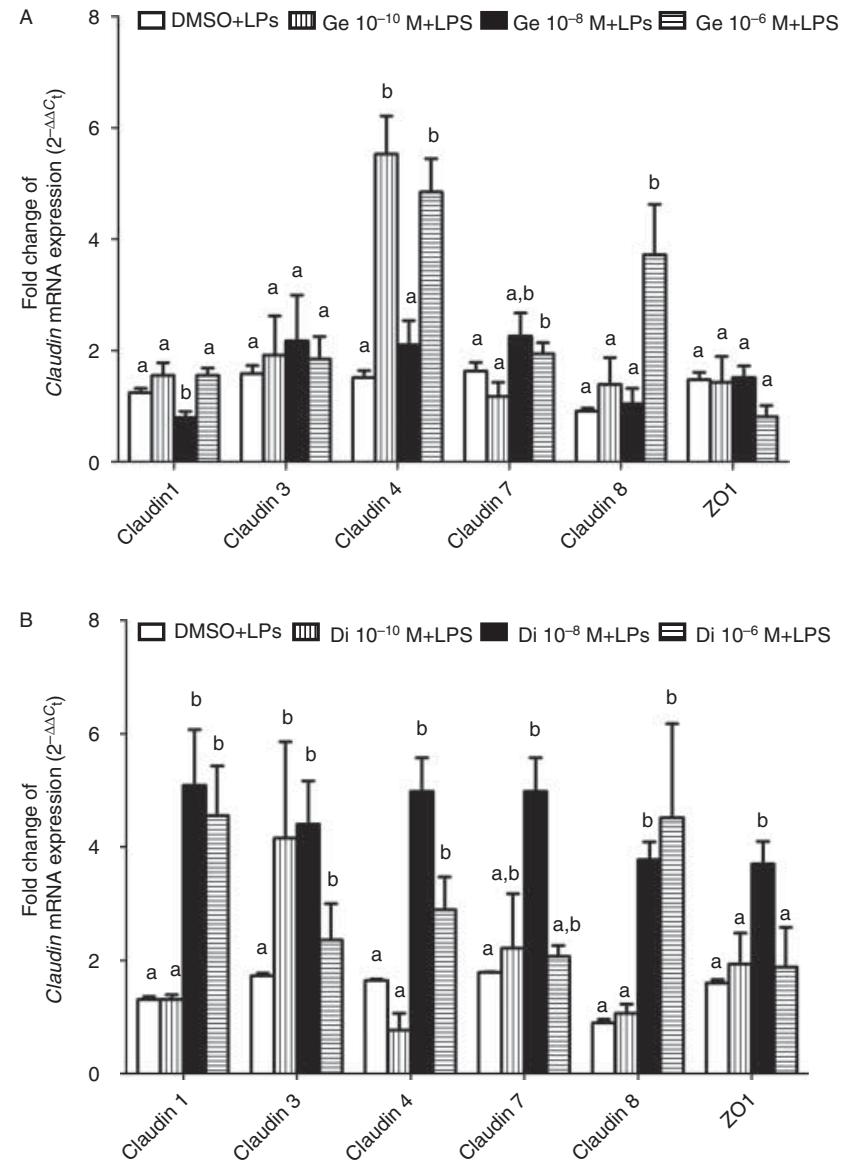

Figure 6 Effects of genistein (A) and daidzein (B) on the relative fold change in mRNA expression of tight junction genes claudin-1, $-3,-4$, $-7,-8, Z O 1$ in the PEG cells. The cells were incubated with $1 \mu \mathrm{g} / \mathrm{ml}$ of LPS for $48 \mathrm{~h}$ after pretreatment with genistein or daidzein at the $10^{-10}$, $10^{-8}$ or $10^{-6} \mathrm{M}$ or vehicle control DMSO. Total RNA was analyzed by real-time RT-PCR. Values are the mean \pm s.E.M. ( $n=6$ in each group). Scale bars with different letters $(a, b)$ mean significantly different at $P$ values $<0.05$.

concentrations, we thus investigated the soy isoflavone effects by using $10^{-10} \mathrm{M}, 10^{-8} \mathrm{M}$, or $10^{-6} \mathrm{M}$ as low, medium, or high concentration (Polkowski \& Mazurek 2000). In addition, the isoflavone effects on TER at the varied time were also focused as its effects have been suggested to be mediated by many pathways depending on time courses, acute vs long-term effects.

This study demonstrated that Ge and Di at specific concentrations affected the barrier function by alterations in TJ permeability in immortalized glandular epithelial monolayer, which have previously represented as an effective model for evaluating the effect of phytoestrogen on electrolyte transport (Deachapunya \& Poonyachoti 2013). The underlying mechanism of these effects was thought to be relevant to alterations in TJ proteins, claudins, and ZO expression, as the genomic effects of these two isoflavonoids have been reported to affect the transcription level of these TJs proteins in intestinal epithelial cells (Suzuki \& Hara 2009).
In the early part of this study, the periodical changes in endometrial TER under vehicle control condition revealed that the percent change in TER began to increase within $30 \mathrm{~min}$, gradually decreased close to the baseline at $24 \mathrm{~h}$, and maintained up to $48 \mathrm{~h}$. This suggests that it requires at least $24 \mathrm{~h}$ to obtain a stable TER after replacement of cells with fresh media. Treatment with high concentration of Ge $\left(10^{-8} \mathrm{M}\right.$ or $10^{-6} \mathrm{M}$ ) did not change the TER profile within the first $24 \mathrm{~h}$, but it significantly increased the TER at $48 \mathrm{~h}$ compared with the control. However, low concentration of Ge $\left(10^{-10} \mathrm{M}\right)$ appeared to slightly decrease the TER at $30 \mathrm{~min}$ and markedly decrease at $24-48 \mathrm{~h}$. This biphasic effect of Ge has been evidenced for studying biological activities in normal and cancer cells (Polkowski \& Mazurek 2000). For example, in breast cancer cells, Ge at high concentration $\left(>10^{-5} \mathrm{M}\right)$ inhibits growth of MCF-7 cells, whereas Ge as low as $10^{-6}$ or $-10^{-8} \mathrm{M}$ stimulates cell growth through the activity of estrogen receptor alpha (ER $\alpha$ ) (Wang et al. 1996). In addition, Ge at the nanomolar range appears to elicit estrogen-like proliferative effects (Martin et al. 1978), but reduces tumor cell proliferation (Dixon-Shanies \& Shaikh 1999) and blocks angiogenesis at the micromolar concentration (Fotsis et al. 1993). Although the underlying mechanisms remain to be explored, the biphasic effect of Ge on the TJ permeability could be attributed to different signaling pathways responsible for different responses. A number of studies have shown that activation of classical ERs by endogenous ligand can disrupt the cytoskeletal architecture, leading to increased endothelial cell permeability (Groten et al. 2005, Aberdeen et al. 2008). On the other hand, high concentration of Ge produces multiple intracellular effects, including inhibition of tyrosine-specific protein kinases (Akiyama et al. 1987, Akiyama \& Ogawara 1991) and topoisomerase II (Markovits et al. 1989). Taken together, it raises possibility that, in this study, high concentration of Ge enhances TJ barrier function through an inhibition of tyrosine kinase, whereas the low concentration of Ge reduces the barrier function through the ER pathway. However, the precise mechanism requires further study.

In addition, the decreased TER within 30 min-2 $\mathrm{h}$ after isoflavones treatment should not be explained by their genomic effects. This observation may correlate with our previous study demonstrating an acute effect of Ge on stimulation of chloride secretion in endometrial cells (Deachapunya \& Poonyachoti 2013). Thus, the reduction in transcellular resistance caused by the opening of chloride ion-conductive pathway may account for the Ge-induced decrease in TER, albeit the TER is mainly dependent on the paracellular pathway (Madara et al. 1988). The increased transepithelial electrolyte transport, providing the driving force for paracellular transport so-called the solvent drag, may be associated.

However, a reduction in TER in response to low concentration of $\mathrm{Ge}$ or $\mathrm{Di}$ is unlikely due to its 
cytotoxicity. The cell viability as assessed by tryphan blue exclusion increased by $20-30 \%$ from initial after 48-h incubation with these isoflavones (observed data). The decreased TER is known to cause the permeation of pro-inflammatory molecules from the lumen, leading to the excessive activation of the mucosal immune system. The immunological responses involve many cytokines and cell-mediated processes, resulting in sustained inflammation and tissue damage. Our results suggest that the soy isoflavonoid-mediated regulation of the endometrial barrier may be partially associated with their biological effects on reproductive organs. A defect in endometrial barrier is involved in several diseases, such as chronic endometritis, endometriosis, or cancer (Martin \& Jiang 2009).

Apart from a weak estrogenic effect by binding to ERs (Kuiper et al. 1997, Kim et al. 1998), the mechanism of $\mathrm{Ge}$ and $\mathrm{Di}$ action has been indicated as inhibitors of tyrosine kinase, although $\mathrm{Di}$ is less potent (Akiyama et al. 1987). Since our recent study using the PEG cells that demonstrated the Ge stimulation of anion secretion via a tyrosine kinase-dependent pathway (Deachapunya \& Poonyachoti 2013), it is possible that the tyrosine kinase-mediated phosphorylation of TJ protein is relevant to Ge effect on regulating TJs expression and function. The phosphorylation status of TJ protein has been suggested to determine TJs structure and function (Rao et al. 1997).

It has been reported that impairment of TJ barrier function is primarily caused by pathogenic bacteria (Ulluwishewa et al. 2011), inflammatory cytokines (Youakim \& Ahdieh 1999, Ahdieh et al. 2001), and reactive oxygen species (Basuroy et al. 2003). The underlying mechanism has been proposed to be mediated through the tyrosine kinase inducing the disassembly of TJ protein complex (Suzuki \& Hara 2009). Therefore, the protective effect of Ge and Di on the decreased endometrial barrier function was continuously examined by challenging PEG cells with bacterial endotoxin O111:B4 E. coli LPSs following 48 h pretreatment with $\mathrm{Ge}, \mathrm{Di}$, or vehicle. The bovine endometrial epithelial and stromal cells have been reported to express TLR4 and MyD88 protein, which binds to LPS and stimulates the cellular release of prostaglandins, cytokines, and chemokines that coordinate the immune and physiological responses including alteration of tissue permeability (Davies et al. 2008, Herath et al. 2009). The expression of toll-like receptors has been identified in the porcine endometrium, although the regulation of TJ barrier function by microorganism has never been indicated (Croy et al. 2009, Østrup et al. 2010). In this study, challenging the PEG cells with LPS significantly decreased TER after $24 \mathrm{~h}$. This finding was consistent with reports of other studies in endometrial cells (He et al. 2009) or intestinal cell monolayers (Chen et al. 2004). Pretreatment with Ge or Di for $48 \mathrm{~h}$ before challenging with LPS inhibited the decreased TER induced by LPS. This evidence suggests the potential effect of these soy isoflavones on prevention of the disrupted TJ barrier function induced by pathogens.

Besides the TER, the effects of Ge and Di on the unidirectional flux of FD-4 with a molecular weight of $4 \mathrm{kDa}$ were further tested for macromolecules transport across the leaky epithelium. Unlike the TER, this FD-4 flux across the PEG cells was not responsive to LPS or both isoflavones pretreatment. However, in the presence of LPS, Ge $\left(10^{-8}\right.$ and $\left.10^{-6} \mathrm{M}\right)$ or $\mathrm{Di}\left(10^{-10}\right.$ and $10^{-6} \mathrm{M}$ ) was found to promote strengthening of PEG as indicated by the increased TER and decreased FD-4 flux. Similar to our study, the permeability of TJ barrier function as assessed by the TER measurement that was not coordinated with the FD-4 flux was previously evidenced in the study of flavonoids in Caco-2 colonic epithelia (Noda et al. 2012). They discussed that the TJ integrity and permeability of Caco-2 colonic epithelia are coordinately regulated by several TJ proteins, in which alterations in protein composition thereby create the variation in paracellular barrier to ions and solutes. TJ proteins indeed have barrier- or pore-forming properties, which allow the paracellular transport of the selected molecules based on charge- and/or size. Many claudins, i.e. claudin- 4 and -8 , have been characterized as a sodium barrier-formers leading to increased TER but not to macromolecules such as $4 \mathrm{Kd}$ FITC-dextran. The different paracellular pathways via the other family of TJ protein occludin, tricellulin, and marvelD3 have been postulated for transport of macromolecules (Raleigh et al. 2010). The paracellular pathway that is permeable to macromolecules has been identified as a 'leak pathway' which is unknown to date, but can be determined by FITC-dextran permeability assay (Krug et al. 2014).

In porcine uterine tissues, the mRNA expression of TJ proteins has been detected (Bailey et al. 2010, Samborski et al. 2013). The expression of claudin-1, -2, -3 and -4 proteins are dynamic through the estrous cycle or pregnancy under the regulation of ovarian sex steroids and placental factors, i.e., estrogen, progesterone, and prolactin (Bailey et al. 2010). We, therefore, further studied whether the changes in TER may be relevant to the genomic effects of $\mathrm{Ge}$ and $\mathrm{Di}$ on the transcription level of claudin and ZO1. The effects of isoflavones on the expression of occludin were not included in this study as it was not affected by LPS (Youakim \& Ahdieh 1999, Al-Sadi \& Ma 2007). Moreover, occludin depletion or knockout did not affect the barrier function of TJs both in vivo and in vitro studies (Schulzke et al. 2005, Xia et al. 2005). This study was the first to detect the expression of TJ mRNA, the claudin- $1,-3,-4,-7$, or -8 , and ZO1 at a higher level than the housekeeping $G A P D H$ in glandular endometrial epithelial cells, with or without LPS inoculation.

Treatment with Ge or Di at $10^{-6} \mathrm{M}$ for $48 \mathrm{~h}$ was found to upregulate claudin-3 and -4 or -8 , respectively, 
suggesting that this effect was mediated via a genomic pathway. Other study has shown the upregulation of claudin- 4 but not claudin-3 in surface and glandular epithelia in response to progesterone level (Bailey et al. 2010). As Ge and Di has an affinity for ERs to produce an estrogenic activity, these isoflavones may regulate transcription of ER-target genes via the estrogenresponsive elements (EREs) present within the gene promoter regions. Even though, claudin-3 and -4 or -8 genes have not been well characterized, our results imply that claudin-3 and -4 or -8 may be the gene target of Ge or Di respectively. It is known that Ge is relatively more potent than $\mathrm{Di}$ and binds to $\mathrm{ER} \beta$ with much higher affinity than ER $\alpha$ (Zava \& Duwe 1997). Thus, the different target genes for Ge and Di action could be mediated by different ER subtypes or other yet unknown mechanisms.

Highly claudin-3 and -4 expressed epithelia not only increase TJ defense function, but also induce cell-to-cell adhesion, as has been suggested in atypical hyperplasia and endometroid adenocarcinoma (Pan et al. 2007, Konecny et al. 2008). In addition, claudin-3 and -4 are homologous to CPE receptor (CPE-R) in the intestine, which is capable for CPE binding and causing cell cytotoxicity (Long et al. 2001). Accordingly, long-term treatment with high concentration of Ge should be taken into consideration and needs to be examined, as it may transform the endometrium to endometroid cancerous cells and susceptible to CPE in human and animals.

Although TJ protein composition is known to correlate with barrier function or tissue permeability, our results revealed that claudin- 8 gene expression was increased by $\mathrm{Di}\left(10^{-8}\right.$ and $\left.10^{-6} \mathrm{M}\right)$ at $48 \mathrm{~h}$ without any difference in the TER. This evidence could be explained by the fact that the expression of several types of claudin proteins seems to be more important than only one type like claudin-8 expression. For an example, distal tubule expressing claudin-1, -3 , and -8 reveals lower electrical resistance than the collecting segment expressing claudin- $1,-3,-4$, and -8 even though they both expressed the claudins-8 (Gonzalez-Mariscal et al. 2003). These findings support ours that why the increased claudin-8 expression induced by $\mathrm{Di} 10^{-8} \mathrm{M}$ did not change the TER as compared with the control which expressed claudins-1, $-3,-4$, and -8 . Nevertheless, the previous study by Amasheh et al. (2009) suggested that increased claudin-8 levels have been shown to promote the sealing of the paracellular barrier.

However, the significance of claudin-3 and -4 expression for the tightening of endometrium could not be dismissed. The Ge $\left(10^{-8} \mathrm{M}\right.$ or $\left.10^{-6} \mathrm{M}\right)$ induced increases in claudin-3 and -4 expressions, but not claudin-8, were shown to be parallel with the increased TER. This finding was supported by the study of endometrium of HIV and endometriosis patients showing that the leakiness of endometrium is due to the result of the decreased claudin-3 or/and -4 expression (Pan et al. 2007, Gaetje et al. 2008, Nazli et al. 2010).

In the PEG cells challenged with LPS, a reduction in TER after $48 \mathrm{~h}$ was correlated with downregulation of claudin-8 mRNA expression and upregulation of claudin-7 and ZO1. The LPS effects on the TJ protein expression have been reported to be mediated through the signaling pathway, resulting in the release of TNF $\alpha$, IL8, and prostaglandin in cultured bovine endometrial epithelial cells (Davies et al. 2008, Herath et al. 2009). In respiratory epithelia, the release of TNF $\alpha$ and IL8, which is mediated by NF- $\kappa B$, p38MAPK, and ERK $1 / 2$ MAPK, has been indicated to relate with the decreased expression of some TJ proteins, i.e. claudin-5 and ZO1, causing an increase in epithelial permeability (Chow et al. 2010). This similar mechanism may apply to the downregulation of claudin-8 by LPS in the PEG cells. Treatment with Ge or $\mathrm{Di}$ was found to restore the downregulated claudin-8 induced by LPS. Even though the underlying mechanism was not investigated in our study, we speculate that Ge or daidazein, wellknown inhibitors of protein kinase activity (Akiyama et al. 1987), may inhibit the downstream signaling of $\mathrm{NF}-\kappa \mathrm{B}$ and thereby restore the LPS downregulated claudin-8.

Interestingly, Ge at all concentrations suppressed the LPS-induced decrease in TER at $48 \mathrm{~h}$, but none of examined TJ gene expression was increased by Ge $10^{-8} \mathrm{M}$ in LPS-inoculated cells (Fig. 6A). Even though Ge $10^{-8} \mathrm{M}$ could not alter the mRNA expression of barrier-forming claudin-1, -3, -4, -8, or ZO1, the other claudin, i.e. claudin-2, which is known as pore-forming claudin generally presented in small intestinal leaky epithelia but not in kidney or endometrium could be induced by LPS. Unfortunately, claudin-2 have low expression and have not been reported as the target of LPS in porcine endometrium. However, the suppressive effects of Ge $10^{-8} \mathrm{M}$ on the LPS-induced claudin-2 should be concerned.

In addition to the alteration of TJs protein expression and function, the alteration of other protein such as myosin light-chain kinase (MLCK) has been proposed to mediate the effect of LPS on decreased TER. It is possible that $\mathrm{Ge} 10^{-8} \mathrm{M}$ may reverse the LPS-induced the decrease in TER through MLCK-dependent pathway. Similar explanations could be applied to the effects of Ge or Di on the increased expression of examined TJ genes during LPS inoculation; however, the exact mechanisms remain to be elucidated.

In conclusion, our results demonstrated that the soy isoflavones $\mathrm{Ge}$ and $\mathrm{Di}$ influences the TJ protein and function in both constitutive and pathogens-activated conditions in endometrial epithelial cells. High concentration $\left(10^{-8}\right.$ to $\left.10^{-6} \mathrm{M}\right)$ of these isoflavones was effective to reveal the promotive effect on the TJ protein expression and barrier function. LPS induced the disruption of the endometrial barrier by the upregulation 
of claudin-7 and ZO1 and downregulation of claudin-8. The impairment of TJ barrier function induced by LPS was ameliorated by pretreatment with soy isoflavones. The possible mechanism of soy isoflavones may be associated with their promotive effects on the claudin-1, $-3,-4,-7,-8$, and ZO1 expression. Thus, the use of soybean isoflavones to restore the barrier function may be a new aspect of the therapy of epithelia weakness during bacterial infection or endotoxemia.

\section{Declaration of interest}

The authors declare that there is no conflict of interest that could be perceived as prejudicing the impartiality of the research reported.

\section{Funding}

This work was supported by research grants from Chulalongkorn University (GRB_APS_27_55_31_04); the 90th Anniversary of Chulalongkorn University Fund (Ratchadapiseksomphot Endowment Fund 13/2554); Srinakharinwirot University (165/2554) awarded to S Poonyachoti, P Kiatprasert, and C Deachapunya.

\section{Acknowledgements}

The authors wish to thank Miss Norathee Buathong for her assistance in this study.

\section{References}

Aberdeen GW, Wiegand SJ, Bonagura TW Jr, Pepe GJ \& Albrecht ED 2008 Vascular endothelial growth factor mediates the estrogen-induced breakdown of tight junctions between and increase in proliferation of microvessel endothelial cells in the baboon endometrium. Endocrinology 149 6076-6083. (doi:10.1210/en.2008-0521)

Ahdieh M, Vandenbos T \& Youakim A 2001 Lung epithelial barrier function and wound healing are decreased by IL-4 and IL-13 and enhanced by IFN- $\gamma$. American Journal of Physiology. Cell Physiology 281 C2029-C2038.

Akiyama T \& Ogawara H 1991 Use and specificity of genistein as inhibitor of protein-tyrosine kinases. Methods in Enzymology 201 362-370. (doi:10.1016/0076-6879(91)01032-W)

Akiyama T, Ishida J, Nakagawa S, Ogawara H, Watanabe S, Itoh N, Shibuya M \& Fukami Y 1987 Genistein, a specific inhibitor of tyrosine-specific protein kinases. Journal of Biological Chemistry 262 5592-5595.

Al-Sadi RM \& Ma TY 2007 IL-1 $\beta$ causes an increase in intestinal epithelial tight junction permeability. Journal of Immunology 178 4641-4649. (doi:10.4049/jimmunol.178.7.4641)

Amasheh S, Milatz S, Krug SM, Bergs M, Amasheh M, Schulzke JD \& Fromm M $2009 \mathrm{Na}^{+}$absorption defends from paracellular back-leakage by claudin-8 upregulation. Biochemical and Biophysical Research Communications 378 45-50. (doi:10.1016/j.bbrc.2008.10.164)

Amasheh S, Fromm M \& Günzel D 2011 Claudins of intestine and nephron - a correlation of molecular tight junction structure and barrier function. Acta Physiologica 201 133-140. (doi:10.1111/j.1748-1716. 2010.02148.x)

Atkinson KJ \& Rao RK 2001 Role of protein tyrosine phosphorylation in acetaldehyde-induced disruption of epithelial tight junctions. American Journal of Physiology. Gastrointestinal and Liver Physiology 280 G1280-G1288.
Bailey DW, Dunlap KA, Frank JW, Erikson DW, White BG, Bazer FW, Burghardt RC \& Johnson GA 2010 Effects of long-term progesterone on developmental and functional aspects of porcine uterine epithelia and vasculature: progesterone alone does not support development of uterine glands comparable to that of pregnancy. Reproduction 140 583-594. (doi:10.1530/REP-10-0170)

Banerjee S, Li Y, Wang Z \& Sarkar FH 2008 Multi-targeted therapy of cancer by genistein. Cancer Letters 269 226-242. (doi:10.1016/j.canlet.2008. 03.052)

Barnes S, Peterson TG, Grubbs C \& Setchell KDR 1994 Potential role of dietary isoflavones in the prevention of cancer. In Diet and Cancer: Markers, Prevention and Treatment, pp 135-148. Ed. MM Jacobs. New York, NY: Plenum Press.

Basuroy S, Sheth P, Kuppuswamy D, Balasubramanian S, Ray RM \& Rao RK 2003 Expression of kinase-inactive c-Src delays oxidative stress-induced disassembly and accelerates calcium-mediated reassembly of tight junctions in the Caco-2 cell monolayer. Journal of Biological Chemistry 278 11916-11924. (doi:10.1074/jbc.M211710200)

Bitto A, Granese R, Triolo O, Villari D, Maisano D, Giordano D, Altavilla D, Marini H, Adamo EB, Nicotina PA et al. 2010 Genistein aglycone: a new therapeutic approach to reduce endometrial hyperplasia. Phytomedicine 17 844-850. (doi:10.1016/j.phymed.2010. 03.024)

Brooks SC \& Skafar DF 2004 From ligand structure to biological activity: modified estratrienes and their estrogenic and antiestrogenic effects in MCF-7 cells. Steroids 69 401-418. (doi:10.1016/j.steroids.2004. 03.014)

Chang HC, Churchwell MI, Delclos KB, Newbold RR \& Doerge DR 2000 Mass spectrometric determination of genistein tissue distribution in dietexposed Sprague-Dawley rats. Journal of Nutrition 130 1963-1970.

Chen J, Tsang LL, Ho LS, Rowlands DK, Gao JY, Ng CP, Chung YW \& Chan HC 2004 Modulation of human enteric epithelial barrier and ion transport function by Peyer's patch lymphocytes. World Journal of Gastroenterology 10 1594-1599.

Chow AW, Liang JF, Wong JS, Fu Y, Tang NL \& Ko WH 2010 Polarized secretion of interleukin (IL)- 6 and IL-8 by human airway epithelia $16 \mathrm{HBE} 140-$ cells in response to cationic polypeptide challenge. PLOS ONE 5 e12091. (doi:10.1371/journal.pone.0012091)

Croy BA, Wessels JM, Linton NF, van den Heuvel M, Edwards AK \& Tayade C 2009 Cellular and molecular events in early and mid gestation porcine implantation sites: a review. Society of Reproduction and Fertility Supplement 66 233-244.

Davies D, Meade KG, Herath S, Eckersall PD, Gonzalez D, White JO, Conlan RS, O'Farrelly C \& Sheldon IM 2008 Toll-like receptor and antimicrobial peptide expression in the bovine endometrium. Reproductive Biology and Endocrinology 6 53. (doi:10.1186/14777827-6-53)

Deachapunya C \& Poonyachoti S 2013 Activation of chloride secretion by isoflavone genistein in endometrial epithelial cells. Cellular Physiology and Biochemistry 32 1473-1486. (doi:10.1159/000356584)

Dixon-Shanies D \& Shaikh N 1999 Growth inhibition of human breast cancer cells by herbs and phytoestrogens. Oncology Reports 6 1383-1387. (doi:10.3892/or.6.6.1383)

Förster C 2008 Tight junctions and the modulation of barrier function in disease. Histochemistry and Cell Biology 130 55-70. (doi:10.1007/ s00418-008-0424-9)

Fotsis T, Pepper M, Adlercreutz H, Fleischmann G, Hase T, Montesano R \& Schweigerer L 1993 Genistein, a dietary-derived inhibitor of in vitro angiogenesis. PNAS 90 2690-2694. (doi:10.1073/pnas.90.7.2690)

Fujita T, Firth JD, Kittaka M, Ekuni D, Kurihara H \& Putnins EE 2012 Loss of claudin-1 in lipopolysaccharide-treated periodontal epithelium. Journal of Periodontal Research 47 222-227. (doi:10.1111/j.1600-0765. 2011.01424.x)

Furuse $M$, Hata M, Furuse $K$, Yoshida $Y$, Haratake A, Sugitani $Y$, Noda $T$, Kubo A \& Tsukita S 2002 Claudin-based tight junctions are crucial for the mammalian epidermal barrier: a lesson from claudin-1deficient mice. Journal of Cell Biology 156 1099-1111. (doi:10.1083/ jcb.200110122)

Gaetje R, Holtrich U, Engels K, Kissler S, Rody A, Karn T \& Kaufmann M 2008 Differential expression of claudins in human endometrium and endometriosis. Gynecological Endocrinology 24 442-449. (doi:10. 1080/09513590802242694) 
Gonzalez-Mariscal L, Betanzos A, Nava P \& Jaramillo BE 2003 Tight junction proteins. Progress in Biophysics and Molecular Biology 81 1-44. (doi:10.1016/S0079-6107(02)00037-8)

Groten T, Pierce AA, Huen AC \& Schnaper HW 2005 17ß-estradiol transiently disrupts adherens junctions in endothelial cells. FASEB Journal 19 1368-1370. (doi:10.1096/fj.04-2558fje)

He D, Su Y, Usatyuk PV, Spannhake EW, Kogut P, Solway J, Natarajan V \& Zhao Y 2009 Lysophosphatidic acid enhances pulmonary epithelial barrier integrity and protects endotoxin-induced epithelial barrier disruption and lung injury. Journal of Biological Chemistry 284 24123-24132. (doi:10.1074/jbc.M109.007393)

Herath S, Lilly ST, Santos NR, Gilbert RO, Goetze L, Bryant CE, White JO, Cronin J \& Sheldon IM 2009 Expression of genes associated with immunity in the endometrium of cattle with disparate postpartum uterine disease and fertility. Reproductive Biology and Endocrinology 755. (doi:10.1186/1477-7827-7-55)

Kim H, Peterson TG \& Barnes S 1998 Mechanisms of action of the soy isoflavone genistein: emerging role for its effects via transforming growth factor $\beta$ signaling pathways. American Journal of Clinical Nutrition 68 1418S-1425S.

Konecny GE, Agarwal R, Keeney GA, Winterhoff B, Jones MB, Mariani A, Riehle D, Neuper C, Dowdy SC, Wang HJ et al. 2008 Claudin-3 and claudin-4 expression in serous papillary, clear-cell, and endometrioid endometrial cancer. Gynecologic Oncology 109 263-269. (doi:10. 1016/j.ygyno.2008.01.024)

Krug SM, Schulzke JD \& Fromm M 2014 Tight junction, selective permeability, and related diseases. Seminars in Cell \& Developmental Biology 16 S1084-S9521. (doi:10.1016/j.semcdb.2014.09.002)

Kuiper GG, Carlsson B, Grandien K, Enmark E, Haggblad J, Nilsson S \& Gustafsson JA 1997 Comparison of the ligand binding specificity and transcript tissue distribution of estrogen receptors $\alpha$ and $\beta$. Endocrinology 138 863-870. (doi:10.1210/endo.138.3.4979)

Long H, Crean CD, Lee WH, Cummings OW \& Gabig TG 2001 Expression of Clostridium perfringens enterotoxin receptors claudin-3 and claudin- 4 in prostate cancer epithelium. Cancer Research 61 7878-7881.

Madara JL, Stafford J, Barenberg D \& Carlson S 1988 Functional coupling of tight junctions and microfilaments in T84 monolayers. American Journal of Physiology 254 G416-G423.

Manach C, Williamson G, Morand C, Scalbert A \& Rémésy C 2005 Bioavailability and bioefficacy of polyphenols in humans: I. Review of 97 bioavailability studies. American Journal of Clinical Nutrition 81 230S-242S

Markovits J, Linassier C, Fossé P, Couprie J, Pierre J, Jacquemin-Sablon A, Saucier JM, Le Pecq JB \& Larsen AK 1989 Inhibitory effects of the tyrosine kinase inhibitor genistein on mammalian DNA topoisomerase II. Cancer Research 49 5111-5117.

Martin TA \& Jiang WG 2009 Loss of tight junction barrier function and its role in cancer metastasis. Biochimica et Biophysica Acta 1788 872-891. (doi:10.1016/j.bbamem.2008.11.005)

Martin PM, Horwitz KB, Ryan DS \& McGuire WL 1978 Phytoestrogen interaction with estrogen receptors in human breast cancer cells. Endocrinology 103 1860-1867. (doi:10.1210/endo-103-5-1860)

Messina MJ 2002 Soy foods and soybean isoflavones and menopausal health. Nutrition in Clinical Care 5 272-282. (doi:10.1046/j.1523-5408. 2002.05602.x)

Nazli A, Chan O, Dobson-Belaire WN, Ouellet M, Tremblay MJ, GrayOwen SD, Arsenault AL \& Kaushic C 2010 Exposure to HIV-1 directly impairs mucosal epithelial barrier integrity allowing microbial translocation. PLoS Pathogens 6 e1000852. (doi:10.1371/journal.ppat. 1000852)

Noda S, Tanabe S \& Suzuki T 2012 Differential effects of flavonoids on barrier integrity in human intestinal Caco-2 cells. Journal of Agricultural and Food Chemistry 60 4628-4633. (doi:10.1021/jf300382h)

Østrup E, Bauersachs S, Blum H, Wolf E \& Hyttel P 2010 Differential endometrial gene expression in pregnant and nonpregnant sows. Biology of Reproduction 83 277-285. (doi:10.1095/biolreprod.109.082321)

Palmer ML, Schiller KR \& O'Grady SM 2008 Apical SK potassium channels and $\mathrm{Ca} 2{ }^{+}$-dependent anion secretion in endometrial epithelial cells. Journal of Physiology 586 717-726. (doi:10.1113/jphysiol.2007. 142877)
Pan XY, Wang B, Che YC, Weng ZP, Dai HY \& Peng W 2007 Expression of claudin-3 and claudin-4 in normal, hyperplastic, and malignant endometrial tissue. International Journal of Gynecological Cancer 17 233-241. (doi:10.1111/j.1525-1438.2006.00748.x)

Polkowski K \& Mazurek AP 2000 Biological properties of genistein. A review of in vitro and in vivo data. Acta Poloniae Pharmaceutica $\mathbf{5 7}$ 135-155.

Raleigh DR, Marchiando AM, Zhang Y, Shen L, Sasaki H, Wang Y, Long M \& Turner JR 2010 Tight junction-associated MARVEL proteins marveld3, tricellulin, and occluding have distinct but overlapping functions. Molecular Biology of the Cell 21 1200-1213. (doi:10.1091/mbc.E0908-0734)

Rao RK, Baker RD, Baker SS, Gupta A \& Holycross M 1997 Oxidant induced disruption of intestinal epithelial barrier function: role of protein tyrosine phosphorylation. American Journal of Physiology 273 G812-G823.

Rao RK, Basuroy S, Rao VU, Karnaky KJ Jr \& Gupta A 2002 Tyrosine phosphorylation and dissociation of occludin-ZO-1 and E-cadherin$\beta$-catenin complexes from the cytoskeleton by oxidative stress. Biochemical Journal 368 471-481. (doi:10.1042/BJ20011804)

Rietjens IM, Sotoca AM, Vervoort J \& Louisse J 2013 Mechanisms underlying the dualistic mode of action of major soy isoflavones in relation to cell proliferation and cancer risks. Molecular Nutrition \& Food Research 57 100-113. (doi:10.1002/mnfr.201200439)

Samborski A, Graf A, Krebs S, Kessler B, Reichenbach M, Reichenbach HD, Ulbrich SE \& Bauersachs S 2013 Transcriptome changes in the porcine endometrium during the preattachment phase. Biology of Reproduction 89 134. (doi:10.1095/biolreprod.113.112177)

Satterfield MC, Dunlap KA, Hayashi K, Burghardt RC, Spencer TE \& Bazer FW 2007 Tight and adherens junctions in the ovine uterus: differential regulation by pregnancy and progesterone. Endocrinology 148 3922-3931. (doi:10.1210/en.2007-0321)

Schulzke JD, Gitter AH, Mankertz J, Spiegel S, Seidler U, Amasheh S, Saitou M, Tsukita S \& Fromm M 2005 Epithelial transport and barrier function in occludin-deficient mice. Biochimica et Biophysica Acta 1669 34-42. (doi:10.1016/j.bbamem.2005.01.008)

Setchell KDR 1998 Phytoestrogens: the biochemistry, physiology, and implications for human health of soy isoflavones. American Journal of Clinical Nutrition 68 1333S-1346S.

Sonoda N, Furuse M, Sasaki H, Yonemura S, Katahira J, Horiguchi Y \& Tsukita S 1999 Clostridium perfringens enterotoxin fragment removes specific claudins from tight junction strands: evidence for direct involvement of claudins in tight junction barrier. Journal of Cell Biology 147 195-204. (doi:10.1083/jcb.147.1.195)

Suzuki T \& Hara H 2009 Quercetin enhances intestinal barrier function through the assembly of zonula occludens-2, occludin, and claudin-1 and the expression of claudin-4 in Caco-2 cells. Journal of Nutrition 139 965-974. (doi:10.3945/jn.108.100867)

Ulluwishewa D, Anderson RC, McNabb WC, Moughan PJ, Wells JM \& Roy NC 2011 Regulation of tight junction permeability by intestinal bacteria and dietary components. Journal of Nutrition 141 769-776. (doi:10.3945/jn.110.135657)

Van Itallie CM \& Anderson JM 2013 Claudin interactions in and out of the tight junction. Tissue Barriers 1 e25247. (doi:10.4161/tisb.25247)

Wang H-J \& Murphy P 1994 Isoflavone content in commercial soybean foods. Journal of Agricultural and Food Chemistry 42 1666-1673. (doi:10.1021/jf00044a016)

Wang TT, Sathyamoorthy N \& Phang JM 1996 Molecular effects of genistein on estrogen receptor mediated pathways. Carcinogenesis 17 271-275. (doi:10.1093/carcin/17.2.271)

Wells CL, Jechorek RP, Olmsted SB \& Erlandsen SL 1993 Effect of LPS on epithelial integrity and bacterial uptake in the polarized human enterocyte-like cell line Caco-2. Circulatory Shock 40 276-288.

Wells CL, Jechorek RP, Kinneberg KM, Debol SM \& Erlandsen SL 1999 The isoflavone genistein inhibits internalization of enteric bacteria by cultured Caco-2 and HT-29 enterocytes. Journal of Nutrition 129 634-640.

Wira CR, Fahey JV, Ghosh M, Patel MV, Hickey DK \& Ochiel DO 2010 Sex hormone regulation of innate immunity in the female reproductive tract: the role of epithelial cells in balancing reproductive potential with 
protection against sexually transmitted pathogens. American Journal of Reproductive Immunology 63 544-565. (doi:10.1111/j.1600-0897. 2010.00842.x)

Xia W, Wong CH, Lee NP, Lee WM \& Cheng CY 2005 Disruption of Sertoligerm cell adhesion function in the seminiferous epithelium of the rat testis can be limited to adherens junctions without affecting the blood-testis barrier integrity: an in vivo study using an androgen suppression model. Journal of Cellular Physiology 205 141-157. (doi:10.1002/jcp.20377)

Youakim A \& Ahdieh M 1999 Interferon- $\gamma$ decreases barrier function in T84 cells by reducing ZO-1 levels and disrupting apical actin. American Journal of Physiology 276 G1279-G1288.
Zava DT \& Duwe G 1997 Estrogenic and antiproliferative properties of genistein and other flavonoids in human breast cancer cells in vitro. Nutrition and Cancer 27 31-40. (doi:10.1080/016355897 09514498)

Received 26 May 2014

First decision 16 June 2014

Revised manuscript received 29 October 2014

Accepted 2 December 2014 